\title{
Perception of farmers on the effect of climate change on poultry production in Osun State, Nigeria
}

${ }^{1}$ Adereti, F. O., ${ }^{2}$ Ibitunde, I. O. and ${ }^{1}$ Adedeji S. O

${ }^{I}$ Department of Agricultural Extension and Rural Development, Obafemi Awolowo

University, Ile-Ife, Nigeria

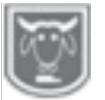

Abstract

${ }^{2}$ Department of Agricultural Economics and Extension, Osun State University, Ejigbo Campus, Nigeria

Climate change plays important role in poultry production, it affects both the egg production aspect of poultry and management. The study was carried out to determine the perception of farmers on the effect climate change on poultry production in Osun State, Nigeria. Specifically, it described the socio economic characteristics of poultry farmers in the study area, determined the perception of the poultry farmers on climate change and identified the problems facing poultry farmers in their production. A multistage sampling procedure was used to select respondents for the study. At the first stage, all the three agricultural zones in the State (Ife/Ilesha, Iwo and Osogbo zones) were selected, at the second stage $40 \%$ of the Local Government Areas (LGAs) in each agricultural zone of the State were randomly selected resulting to five LGAs from Osogbo zone, 4 LGAs in Ife/Ilesha zone and LGAs from Iwo zone. This gave a total of $12 \mathrm{LGAs}$ all. At the final stage 10 communities were selected from each $L G A$ and 10 respondents were selected randomly from the selected communities resulting to a total of 120 respondents. Structured interview schedules were designed in English and used to elicit data from the respondents. Data collected were analyzed using both descriptive and inferential statistics such as frequency counts, percentages, mean and standard deviation. The results showed that more than majority (65.8\%) of the respondents were males. The mean age of the respondents was $43.72 \pm 10.51$ years. The mean of household size was $5.21 \pm 1.84$.

In addition, climate changes affected the farmers rearing season of poultry birds (5.32) ranked highest among the respondents' perception on climate change followed by farmers' decision making concerning the type of livestock to rear can be affected by climate change (5.10). Diseases (4.61) ranked highest among the effects of climate change on farmers' poultry production followed by infertility (3.21). Diseases and parasites (1.00), inadequate access to feed (1.00) and cost of feed (1.00) ranked highest and equally among the problems facing poultry farmers in their production. The study concluded that majority of the farmers were aware that climate change has negative effect on poultry production. It was recommended that more awareness on effect of climate change on poultry production should be created and that farmers should engage professionals like veterinary doctors to manage the health of their poultry.

Keywords: Perception, effect, climate change, poultry production.

\section{Perception des agriculteurs sur l'effet du changement climatique sur la production de volaille dans l'État d'Osun, Nigéria}

\section{Résumé}

Le changement climatique joue un rôle important dans la production de volaille, il affecte à la fois l'aspect de la production d'oufs de la volaille et la gestion. L'étude a été réalisée pour déterminer la perception des agriculteurs sur l'effet du changement climatique sur la 


\section{Perception of farmers on the effect of climate change on poultry production}

production de volaille dans l'État d'Osun, au Nigéria. Plus précisément, il a décrit les caractéristiques socio-économiques des aviculteurs dans la zone d'étude, déterminé la perception des aviculteurs sur le changement climatique et identifié les problèmes auxquels sont confrontés les aviculteurs dans leur production. Une procédure d'échantillonnage à plusieurs degrés a été utilisée pour sélectionner les répondants pour l'étude. À la première étape, les trois zones agricoles de l'État (zones Ife / Ilesha, Iwo et Osogbo) ont été sélectionnées, à la deuxième étape 40\% des zones de gouvernement local (LGA) de chaque zone agricole de l'État ont été sélectionnées au hasard résultant de cinq LGA de la zone Osogbo, 4 LGA de la zone Ife / Ilesha et des LGA de la zone Iwo. Cela a donné un total de 12 LGA. Au stade final, 10 communautés ont été sélectionnées dans chaque LGA et 10 répondants ont été sélectionnés au hasard parmi les communautés sélectionnées, soit un total de 120 répondants. Les calendriers d'entrevue structurés ont été conçus en anglais et utilisés pour obtenir des données auprès des répondants. Les données recueillies ont été analysées à l'aide de statistiques descriptives et inférentielles telles que les nombres de fréquences, les pourcentages, la moyenne et l'écart type. Les résultats ont montré que plus de la majorité $(65,8 \%)$ des répondants étaient des hommes. L'âge moyen des répondants était de 43. $72 \pm 10,51$ ans. La taille moyenne des ménages était de 5,21 $\pm 1,84$.

En outre, les changements climatiques ont affecté la saison d'élevage des volailles par les agriculteurs $(5,32)$ classée au premier rang parmi la perception des répondants sur le changement climatique, suivie par la prise de décision des agriculteurs concernant le type de bétail à élever peut être affecté par le changement climatique (5.10). Parmi les effets du changement climatique sur la production de volaille des agriculteurs, les maladies $(4,61)$ se classaient au premier rang, suivies de l'infertilité $(3,21)$. Les maladies et les parasites $(1,00)$, l'accès insuffisant aux aliments pour animaux $(1,00)$ et le coût des aliments $(1,00)$ se classaient au premier rang et à égalité parmi les problèmes auxquels les aviculteurs étaient confrontés dans leur production. L'étude a conclu que la majorité des agriculteurs étaient conscients que le changement climatique a un effet négatif sur la production de volaille. Il a été recommandé de sensibiliser davantage aux effets du changement climatique sur la production de volaille et que les agriculteurs engagent des professionnels tels que les médecins vétérinaires pour gérer la santé de leurs volailles.

Mots clés: perception, effet, changement climatique, production avicole.

\section{Introduction}

Climate variation is a persistent change in the mean of climate parameters (temperature, rainfall, humidity and soil moisture) due to change in the composition of atmospheric gases. Krishna (2011) stated that the change in the atmospheric composition is attributed to the emissions of greenhouse gases (GHG) such as Carbon dioxide $\left(\mathrm{CO}_{2}\right)$, Methane $\left(\mathrm{NH}_{4}\right)$, Nitrogen oxide $\left(\mathrm{N}_{2} \mathrm{O}\right)$ and other gases. Climate variation is a shift in the average weather that a given area experiences. It occurs over a period of time which may range from several decades to centuries. It has been observed across the globe that there has always been a change in the climate of an area for a period of 30-10Oyrs manifesting in earthquakes, flooding, tsunami, tornadoes, fluctuations in rainfall and temperature. Intergovernmental Panel on Climate Change (2012) made it certain that climate variation is taking place. Climate variation is a global issue because it does not only affect the poor and developing countries but is also facing the developed world with flooding, earthquakes, cyclones, tornadoes and wild fires. It is clear that climate variation in many parts of the world adversely affects socioeconomic sectors which include water resources, agriculture, 


\section{Adereti, Ibitunde and Adedeji}

forestry, fisheries and animal husbandry. It is a phenomenon that will continue to occur; mitigating its is the only way out. The intricacy of climate variation is now receiving so muchion due to its impacts on both living and non-living creatures (Osaguona, 2009). Farmers are facing a lot of challenges due to climate variation and it may not be clear in empirical terms what loss farmers incur but it is known to cause more harm to their production than good. There are many human factors that are responsible for climate variation across the globe like poor environmental sanitation, deforestation, bush burning, drilling of boreholes, fuel combustion, and cement manufacture.

Agriculture is responsible for 14 percent of global Green House Gases (GHG) emissions and livestock plays a considerable role in climate variation in terms of their contribution to GHG emissions (Steinfeld et al., 2006; Krishna, 2011). The greatest effect of climate variation has however been predicted to be in the animal production in Sub- Saharan Africa which include Nigeria (Adesoji and Famuyiwa, 2010). Livestock accounts for 40 percent of agricultural Gross Domestic Product (GDP) and employs 1.3 billion people while supporting the livelihoods of one billion of the world's poor (Food and Agriculture Organization, 2007). Poultry production is a major source of protein which has empowered poultry farmers to secure a means of survival and livelihood. Climate variation affects poultry production by reducing poultry yield and nutritional quality of feeds, increasing disease and disease-spreading pests, reducing water availability and making it difficult for birds to survive (Spore, 2008). Climate variation manifests as rise in temperature causing a fall in humidity and provides a medium for fungal and bacterial growth. Disease outbreak becomes inevitable; diseases like coccidiosis, hemorrhagic syndrome, fowl pox, and bronchitis will thus be on the increase. Rowlinson (2008) stated that change in temperature will reduce the rate of poultry feed intake causing poorer performance. Given that the effects of climate variation can only be mitigated; it is pertinent to determine a forehand the perceived effect of the trend by the people most involved. Climate change may affect poultry production in several ways. It may have indirect impacts, influencing production inputs (corn, soy, electricity, etc.), as well as direct impacts, generated by the constant increase in environmental temperature over the years (productivity and egg quality losses) or by the incidence of extreme temperature events (mortality). Poultry production and reproduction are affected by various factors such as, feeding, management, disease control, stock density, housing, climate, sire effect, hatch effect, etc. Research has generated information and techniques to deal with most of these factors except the climate change in order to maximize production. All poultry farmers agree that poultry keeping is an excellent tool in poverty alleviation due to the quick turnover and low investment. Improvement in poultry production implies to create an opportunity for development of the poor section of the society. However, climate change is emerging as a great challenge for poultry industries to sustain the level of production. The worst effects of such climate change are experienced in tropical countries where, a common practice is to house the birds in the open side sheds. Climate variation is one of the major threats to poultry production. Birds of different breeds/strains and of different age, sex, stage of production, and reproduction respond differently to climatic variations. It is highly desirable that data on such effects in different flocks should be generated and analyzed to develop strategies to deal with adverse effects of climate change.

\section{Statement of problem}




\section{Perception of farmers on the effect of climate change on poultry production}

change impacts on poultry productions and the negative impacts of livestock production on climate change, various reports of research findings also focused on negative impacts of climate change on disease occurrences of birds and effects of food-feed competitions on chicken production but the knowledge and perception of the poultry farmers on the effect of climate change can actually be the difference between profit and loss of poultry farmers and this is the problem that this research is set to address. Despite technological advances, such as improved varieties, genetically modified organisms, and irrigation systems, weather is still a key factor in agricultural productivity, as well as soil properties and natural communities. The effect of climate on agriculture is related to variabilities in local climates rather than in global climate patterns. A farmer having adequate knowledge of climate change and good perception of the effect on his/her poultry production can allow the farmer to take necessary precautions in planning ahead to minimize loss or even to use it for his or her advantage. Many findings have been done on climate change but there is little empirical evidence on the perception of farmers on the effect of climate change on poultry production, hence this study focused on these perceptions of farmers on the effects of climate change on poultry production in Osun State, Nigeria.

\section{Materials and methods}

The study area was Osun State. A multistage sampling procedure was used to select respondents for the study. At the first stage, all the three agricultural zones in the State (Ife/Ilesha, Iwo and Osogbo zones) were selected, at the second stage $40 \%$ of the Local Government Areas (LGAs) in each agricultural zone of the State were randomly selected resulting to 5 LGAs from Osogbo zone, 4 LGAs in Ife/Ilesha zone and LGAs from Iwo zone. This gave a total of 12
LGAs all. At the final stage 10 communities were selected from each LGA and 10 respondents were selected randomly from the selected communities resulting to a total of 120 respondents. Structured interview schedules were designed in English and used to elicit data from the respondents. Data collected were analyzed using both descriptive and inferential statistics such as frequency counts, percentages, mean and standard deviation; Chi-square and correlation analyses were used to draw inferences from the hypotheses.

\section{Results and discussion \\ Socio economic characteristics of the respondents}

Results in Table 1 showed that majority $(65.8 \%)$ of the respondents were male while 34.2 per cent of the respondents were female. This implies that we have more males practicing in poultry farming than females this can be due to the rigorous activities involved in the business. The results further showed that that the mean age of the respondents was 43.72 years. This implies that most of the farmers were just above the youth age. This result agrees with the findings of Olagunju and Babatunde (2011) which reported that the mean age of poultry farmers was 46 years. The results further showed that almost half $(45.8 \%)$ of the respondents were married which is highest respondents' percentages. This implies that there were more married poultry farmers among the respondents, the responsibilities they carried might be the reason why some of them were into the poultry farming. This result contradicts the research of Alade and Ademola (2013) which reported that ma larger respondents' percentage $(73.3 \%)$ were married. The mean of household size was $5.21 \pm 1.84$. This implies that respondents were careful in giving birth to children, this will allow them to give each and every one of the good and quality education. 
Table 1: Distribution of respondents according to their socio economic characteristics $(\mathrm{n}=120)$

\begin{tabular}{lll}
\hline Characteristics & Frequency & Percentage \\
\hline Age (years) & & \\
$<30$ years & 8 & 6.7 \\
$30-39$ & 40 & 33.3 \\
$40-49$ & 42 & 35.0 \\
$50-59$ & 17 & 14.2 \\
60 and above & 13 & 10.8 \\
Mean & $\mathbf{4 3 . 7 2 \pm \mathbf { 1 0 . 5 1 }}$ \\
Gender & & \\
Male & 79 & 65.8 \\
Female & 41 & 34.2 \\
Marital status & & \\
Married & 93 & 77.5 \\
Single & 19 & 15.8 \\
Widowed & 8 & 6.7 \\
Household size & & \\
$<3$ & 1 & 0.83 \\
3-5 & 76 & 63.3 \\
6-8 & & 27.5 \\
Mean & 33 & 8.3 \\
\hline
\end{tabular}

Source: Field Survey 2019

Perception of poultry farmers on climate change

The results in Table 2 showed the perception of poultry farmers on climate change, the results were ranked using the mean of each perception. The statement "Climatic changes affect the farmers rearing seasons of poultry birds" was ranked 1 st with mean of 5.32, the statement "Farmers decision making concerning the type of crop to farm or livestock to rear can be affected by climatic changes" was ranked second with the mean of 5.10. The statement "Climatic changes affect the rate at which poultry birds are affected by various diseases" was ranked third with mean of 4.82. Fourthly ranked is the statement "Changes in climate affect temperature changes in the study area" with the mean of 4.28. Furthermore, the fifth ranked on the Table is "Climatic changes affect water intake of poultry birds" with mean of 2.91, this agrees with the Elijah and Adedapo (2006) research in which it was stated that $78.4 \%$ of the respondents agreed that high temperature makes birds feed less and drink more water; this is because temperature reduces the feed intake of poultry birds and more energy is needed to conserve the heat caused by high temperature, hence, a decreased in the rate of feed intake which results to decrease in egg and meat production. Also, the $6^{\text {th }}$ ranked on the Table is "Climatic changes affect the quality of eggs laid" with mean of 2.73. From the Table the results showed that "Climatic changes affect the rate of feed intake" is the $7^{\text {th }}$ ranked with the mean of 2.41. The $8^{\text {th }}$ ranked perception on the Table is "Climate change can be used to predict the weather conditions" with the mean of 2.22. The Table showed the $9^{\text {th }}$ ranked perception which is "Climatic changes affect the growth of the poultry birds" with the mean of 2.01. "Climate change is about increase in the number of days of dry spell" with the least mean of 1.11 ranked 10 . The results of the research agree with the same findings of Elijah and Adedapo (2006), in which it was stated that temperature fluctuation and increased sunshine intensity has negative consequence on poultry 


\section{Perception of farmers on the effect of climate change on poultry production}

production resulting in high mortality of the chickens, low egg production and low feed in take with low production. Intensive poultry industries rely heavily on cereals grains as such as maize as their principal feed type, climate change will likely have the potential to affect the availability of the feed grain which will put pressure on the poultry industries.

Table 2: Determination of the perception of poultry farmers on climate change $(n=120)$

\begin{tabular}{|c|c|c|c|c|c|c|c|}
\hline Statements & SA & $\overline{\mathbf{A}}$ & UD & D & SD & $\begin{array}{l}\text { Mean } \\
\text { score }\end{array}$ & Rank \\
\hline $\begin{array}{l}\text { Climatic changes affect the } \\
\text { farmers rearing seasons of } \\
\text { poultry birds }\end{array}$ & $\begin{array}{l}117 \\
(97.5)\end{array}$ & $3(2.5)$ & 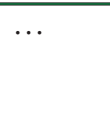 & $2 \ldots .$. & $2 \ldots$ & 5.32 & $1^{\mathrm{st}}$ \\
\hline $\begin{array}{l}\text { Farmers decision making } \\
\text { concerning the type of crop to } \\
\text { farm or livestock to rear can be } \\
\text { affected by climatic changes }\end{array}$ & $89(74.2)$ & $\begin{array}{l}25 \\
(20.8)\end{array}$ & $6(5.0)$ & $\ldots \ldots$ & $\ldots$ & 5.10 & $2^{\text {nd }}$ \\
\hline $\begin{array}{l}\text { Climatic changes affect the rate } \\
\text { at which poultry birds are } \\
\text { affected by various diseases }\end{array}$ & $\begin{array}{l}101 \\
(84.2)\end{array}$ & $\begin{array}{l}18 \\
(15.0)\end{array}$ & $1(0.8)$ & $\ldots \ldots$ & $\ldots$ & 4.82 & $3^{\text {rd }}$ \\
\hline $\begin{array}{l}\text { Changes in climate affect } \\
\text { temperature changes in the } \\
\text { study area }\end{array}$ & $\begin{array}{l}116 \\
(96.7)\end{array}$ & $2(1.7)$ & $2(1.7)$ & $\ldots$. & $\ldots$ & 4.28 & $4^{\text {th }}$ \\
\hline $\begin{array}{l}\text { Climatic changes affect water } \\
\text { intake of poultry birds }\end{array}$ & $71(59.2)$ & $\begin{array}{l}44 \\
(36.7)\end{array}$ & $5(4.2)$ & $\ldots \ldots$ & $\ldots$ & 2.91 & $5^{\text {th }}$ \\
\hline $\begin{array}{l}\text { Climatic changes affect the } \\
\text { quality of eggs laid }\end{array}$ & $1(0.8)$ & $\begin{array}{l}35 \\
(29.2)\end{array}$ & $\begin{array}{l}53 \\
(44.2)\end{array}$ & $\begin{array}{l}23 \\
(19.2)\end{array}$ & $8(6.7)$ & 2.73 & $6^{\text {th }}$ \\
\hline $\begin{array}{l}\text { Climatic changes affect the rate } \\
\text { of feed intake }\end{array}$ & $54(45.0)$ & $\begin{array}{l}57 \\
(47.5)\end{array}$ & $9(7.5)$ & $\ldots \ldots$ & $\ldots$ & 2.41 & $7^{\text {th }}$ \\
\hline $\begin{array}{l}\text { Climate change can be used to } \\
\text { predict the weather conditions }\end{array}$ & $61(50.8)$ & $\begin{array}{l}55 \\
(45.8)\end{array}$ & $4(3.3)$ & $\ldots .$. & $\ldots$ & 2.22 & $8^{\text {th }}$ \\
\hline $\begin{array}{l}\text { Climatic changes affect the } \\
\text { growth of the poultry birds }\end{array}$ & $62(51.7)$ & $\begin{array}{l}55 \\
(45.8)\end{array}$ & $3(2.5)$ & $\ldots$. & $\ldots$ & 2.01 & $9^{\text {th }}$ \\
\hline $\begin{array}{l}\text { Climate change is about } \\
\text { increase in the number of days } \\
\text { of dry spell }\end{array}$ & $39(32.5)$ & $\begin{array}{l}37 \\
(30.8)\end{array}$ & $\begin{array}{l}34 \\
(28.3)\end{array}$ & $9(7.5)$ & $1(0.8)$ & 1.11 & $10^{\text {th }}$ \\
\hline
\end{tabular}

KEY:SA = Strongly Agree; A = Agree; UD = Undecided; D = Disagree; SD = Strongly Disagree.

Note: figures in parenthesis are percentages

Source: Field Survey, 2019

Identification of the effect of climate change on farmers' poultry production

Results in Table 3 showed the effect of climate change on farmers' poultry production, from the results, diseases had the highest effect of climate change on farmers' poultry production with $(61.66 \%)$. Next in the rank is Infertility with (18.33\%). Dehydration has a percentage of 8.33. next was low feed intake (6.67\%) while defecation has the lowest effect of climate change on farmers' poultry production with
$(5 \%)$. The table 5 showed that defecation had the least effect that the farmers usually experienced while diseases are the most effects that the farmers usually experience. Elijah and Adedapo (2006) reported also that climate change has an effect with poultry feed intake, encourage outbreak of poultry diseases which invariably reduce egg production.

\section{Problem facing poultry farmers in their production}

Table 4 shows the problem facing poultry 
farmers in their production. Thus, from the Table 4, the results showed that the problems with the highest mean: disease and parasite $($ mean $=1)$, access to adequate feeds (mean $=1$ ), and cost of feeds (mean $=1$ ). This implies that the three problems posed serious threat to farmers involved in poultry production. The next highest ranked problem was termed "access to right birds" (mean $=0.59)$, this means that poultry farmers had difficulties in recognizing and locating right birds for their poultry production. The next and the least problem was lack of information (mean $=0.38$ ), this implies that information is not a major problem to farmers.

Tab le 3: Identification of the effect of climate change on farmers' poultry production $(\mathbf{n}=120)$

\begin{tabular}{lllll}
\hline Effects of climate change & Frequency & Percentage & Mean score & Rank \\
\hline Dehydration & 10 & 8.33 & 2.11 & $3^{\text {rd }}$ \\
Infertility & 22 & 18.33 & 3.21 & $2^{\text {nd }}$ \\
Diseases & 74 & 61.66 & 4.61 & $1^{\text {st }}$ \\
Low feed intake & 8 & 6.67 & 0.41 & $4^{\text {th }}$ \\
Defecation & 6 & 5.0 & 0.22 & $5^{\text {th }}$ \\
\hline
\end{tabular}

Source: Field Survey, 2019

Table 4: Problems facing poultry farmers in their production $(n=120)$

\begin{tabular}{lll}
\hline \hline Problems facing poultry farmers & Yes & Mean \\
\hline Lack of information & Frequency (\%) & \\
Diseases and parasites & $45(37.5)$ & 0.38 \\
Access to adequate feed & $120(100)$ & 1.00 \\
Cost of feed & $120(100)$ & 1.00 \\
Access to right birds & $120(100)$ & 1.00 \\
\hline
\end{tabular}

Source: Field Survey, 2019

\section{Conclusion and recommendation}

The study concluded that majority of the farmers were aware that climate change has negative effect on poultry production. It was recommended that more awareness should be created on the effects of climate change on poultry production and that awareness should be created for the farmers on how each farmer can produce their own feed.

\section{References}

Adesoji, S. A. and Famuyiwa, B. S. 2010. Perception and Adaptation to Climate Change among Fulani Cattle Rearers in Osun State, Nigeria. Proceedings of 15th Annual National Conference, AESON 10-14th May, 2010.

Alade, O. A. and Ademola, A. O. 2013.
Perceived Effect of Climate Variation on Poultry Production in Oke Ogun Area of Oyo State. Journal of Agricultural Science; Vol. 5, No. 9.

Intergovernmental Panel on Climate Change. 2001. Climate Change: Synthesis Report. In R. T. Watson and the Core Writing Team (Eds.), A Contribution of Working Group I, II and III to the $T h i r d$ Assessment Report of the Intergovernmental Panel on Climate Change.

Krishna, P. P. 2011. Economics of Climate variation for small holder farmers in Nepal: A review Journal of Agriculture and Environment, 12, 6-3

Olagunju, F. I. and Babatunde, R. O. 2011. Impact of credit on poultry 
productivity in southwestern Nigeria. Journal of Agricultural and Biological Science Vol. 6(10)

Osaguona, P. O., Fajobi, E. A., Meduna A. J., Irokanulo, U. O., Ayeni, S. M. and Ogunjobi, J.A. 2007 . Effect of Climate Variation on the Environment. Proceedings of the Association of Women $i \quad n$ Forestry and Environment (pp. 167-170).

Steinfeld, H., Gerber, P., Wassenaar, T., Castel, V., Rosales, M. and de Hann, C. 2006. Livestock's Long Shadow: Environmental Issues and Options. Rome: FAO.

Elijah, O. A. and Adedapo, A. 2006. The effect of climate on poultry productivity in Ilorin, Kwara State, Nigeria. International Journal of Poultry Science, 5(11), 1061-1068.
Food and Agriculture Organization. 2007. Adaptation to Climate Change in Agriculture, Forestry and Fisheries: Perspectives, Framework and Priorities. Rome: FAO.

Rowlinson, P. 2008. Adapting Livestock Production Systems to Climate Variation-Temperate Zones. Livestock and Global Change Conference Proceeding, May 2008, Tunisia.

Spore Magazine. 2008. Climate Variation: Pests and Diseases.Spore Magazine, August Special Issue: CTA.pp. 5-6.

Received: $12^{\text {th }}$ October, 2020 Accepted: $5^{\text {th }}$ February, 2021 